\title{
含水率が火災加熱を受ける木材の力学的性能へ及ぼす影響
}

一多様な含水状態におけるスギ及びケヤキの高温時ヤング係数・曲げ強度の測定一

\section{INFLUENCE OF WATER CONTENT ON THE MECHANICAL PROPERTIES OF WOOD EXPOSED TO FIRE}

- Young's modulus and bending strength of Cryptomeria Japonica and Zelkova serrate under various water-containing states at elevated temperature -

\author{
加 來 千 紘*1, 長谷見 雄二*2, 上川大輔*3, 鈴木 達 朗*4, \\ 安井昇 ${ }^{* 5}$, 腰原幹雄 ${ }^{* 6}$, 長尾博文*7 \\ Chihiro KAKU, Yuji HASEMI, Daisuke KAMIKAWA, Tatsuro SUZUKI, \\ Noboru YASUI, Mikio KOSHIHARA and Hirofumi NAGAO
}

\begin{abstract}
The mechanical properties of Cryptomeria Japonica, a softwood commonly used in timber engineering, and Zelkova serrata, a hardwood normally used in traditional large buildings, heated up to $95^{\circ} \mathrm{C}$ were measured at the elevated water content and temperatures as an engineering basis for the structural fire safety design of large-scale timber buildings. The results show that the Young's modulus of two species at the elevated water content and temperatures was largely affected by the water content over $5 \%$ and the heating temperatures $80^{\circ} \mathrm{C}$ or higher. The bending strength at normal temperature or higher was highly dependent on the water content, however two species showed different declining trends with the rise of water content and temperatures. The correlation between Young's modulus and bending strength of Cryptomeria Japonica and Zelkova serrate keep to the same with the rise of the water content and temperatures.
\end{abstract}

Keywords : Young's modulus, bending strength, temperature dependence, water content dependence, structural timber elements ヤング係数, 曲げ強度, 温度依存性, 含水率依存性, 木構造部材

1. はじめに

近年、大規模木造建築を可能とする法的整備や木質材料の技術開 発が進められ、木構造による中層・大規模建築も実現され始めてい る。木材は、材ごとに物性のばらつきを持つ自然材料であるが、常 温における力学的性能は、含水率の上昇に伴い低下寸ることが知ら れている 1) 4)等。そのため、中層・大規模木造建築において木構造 の力学的性能を担保するためには、部材のヤング係数及び含水率を 把握し材料管理することが必要不可欠である。しかしながら、部材 断面全体を平衡含水率とすることは技術的に非常に高度であること から、材料管理された材においても部材内部に含水率分布が存在し、 部分的に日本農林規格（JAS）等における含水率の規定值よりも高 い状態となることが考えられる。

また大規模木造建築の多くは、火災最盛期での崩壊を免れる高度 な防耐火性能を有する大断面木構造部材の利用が前提とされる。耐
火構造や準耐火構造、燃えしろ設計による木構造部材が、火㷋最盛 期を通じて構造部材としての基本的性能を満足するためには、火災 加熱が部材断面の力学的性能に及ぼす影響を把握・制御する必要が ある。これまでも火災加熱下での木材や木部材の炭化速度や力学的

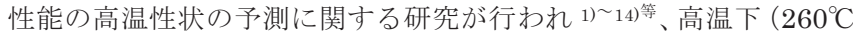
未満）での木材のヤング係数及び曲げ強度は、温度の上昇に伴い低 下寸ることが明らかにされている ${ }^{6)}$ 等。しかし、これらは含水率 の影響を排除するためほぼ全乾状態となるよう乾燥させた試験体を 用いた実験により検証されている。そのため、木材の含水率依存性 が温度に係らず不変でない限り、気乾状態および湿潤状態の木材は、 温度に対する力学的性能の低下率が全乾状態の木材とは異なる可能 性がある。更に、火災加熱を受ける木材は、内部に水蒸気圧分布が 生じることで水分が低温側へと移動し、部分的に火災前の含水率よ

本論文の実験の骨子及び結果の概要については，文献 18),19)で口頭発表した。

*1 早稲田大学大学院 工修

Graduate School of Waseda Univ., M.Eng.

*2 早稲田大学理工学術院 教授. 工博

*3 国立研究開発法人森林総合研究所 博士 (工学)

*4 早稲田大学大学院

*5 早稲田大学理工学研究所 招聘研究員 · 博士 (工学)

*6 東京大学生産技術研究所教授・博士 (工学)

*7 国立研究開発法人森林総合研究所

Prof., Dept. of Architecture, Waseda Univ., Dr.Eng.

Forestry and Forest Products Research Institute, Ph.D.

Graduate School of Waseda Univ.

Visiting Researcher, RISE, Waseda Univ., Ph.D

Prof., Institute of Industrial Science, The University of Tokyo, Ph.D.

Forestry and Forest Products Research Institute 
りも高い状態となる ${ }^{15)}$ 。含水率の上昇に伴い木構造部材の力学的性 能が低下寸れば、火災加熱時にも荷重を支持し続けることが期待さ れる比較的低温の部分の非損傷性を低下させる危険性がある。これ らの理由により火災加熱を受ける木構造部材を問題にする場合、一

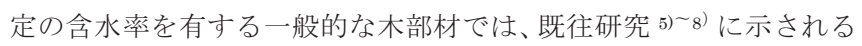
温度依存性だけでは、火災時の力学的性能の低下を説明できないこ とが予想される。しかし、木材の力学的性能に対する含水率の影響 は、常温では品質管理への関心から研究されてきたが、高温下での 影響の程度に関する研究例は見当たらない。

以上を踏まえ本研究では、火災加熱を受ける木構造部材の力学的 性能に対する含水率の影響を明らかにするため、水分の蒸発が顕著 とならない $100^{\circ} \mathrm{C}$ 未満の温度範囲で、大断面木構造部材に用いられ るスギ及びケヤキ製材の無欠点小試験体について曲げ試験を行い、 ヤング係数及び曲げ強度に及ぼす含水率の影響を実験的に把握する。

\section{2. 検討方法}

木材は繊維飽和点以下において、常温時の力学的性能に含水率依 存性があり 1) 4) 等、また含水率 $5 \%$ 近傍では、ヤング係数及び曲げ 強度について樹種ごとに温度依存性がある ${ }^{6)}$ ８）等との報告がある。 そこで本研究では、含水率、温度及び樹種をパラメータとし、まず $100^{\circ} \mathrm{C}$ 未満の各温度下における木材の力学的性能の含水率依存性を 把握する。その上で、火災加熱を受ける木構造部材の力学的性能変 化を念頭に、含水率が木材の温度と力学的性能の関係へ及ぼす影響 について考察寸る。試験体には、大断面木構造部材に使用される代 表的な針葉樹材としてスギを、伝統的大規模建築物に使われる広葉 樹材の代表的なものとしてケヤキを選定した。木材の含水率を高い 精度で制御・管理することは困難であるため、本研究の試験体の含 水状態については、木材の力学的性能と含水率の関係及び大断面木 構造部材において想定される含水率の範囲を考慮し、以下（1）～

（4）の試験体群を目標に試験体を用意した。また各試験体群に関 して 4 つの温度帯（常温及び $50^{\circ} \mathrm{C} 、 80^{\circ} \mathrm{C} 、 95^{\circ} \mathrm{C}$ ) でヤング係数及 び曲げ強度を算定した。

（1）試験体群 $\mathrm{A}$ ：含水率 $\mathrm{W} \leqq 5 \%$

木材の力学的性能が最も高まる含水率範囲 1,2)

（2）試験体群 B： $5 \%<$ 含水率 $\mathrm{W} \leqq 15 \%$

材料管理された中大断面の木構造部材の一般的な含水率範囲

（3）試験体群 C：15\%<含水率 $\mathrm{W} \leqq 30 \%$

木構造部材の部分的な高含水状態かつ木材の力学的性能への 影響が大きい結合水の上限（繊維飽和点 1) 3)）を想定とした 含水率範囲

（4）試験体群 D：含水率 W $>30 \%$

木材の繊維飽和点以上 (自由水の変化のみを想定) とした含水 率範囲

実験は、全長 $320 \mathrm{~mm}$ の無欠点小試験体により、まず常温下で試 験体の強度に影響しない範囲の加力試験（以後、「非破壊試験」）に より常温時のヤング係数を測定した後、4 段階に設定した試験体群 ごとに、常温を含む所定の各温度で試験体が破断に至るまで加力す る試験（以後、「破壊試験」）を行い、ヤング係数及び曲げ強度を算 定した。

温度及び含水率が木材の力学的性能に及ぼす影響を定量的に把握
するため、まず乾燥状態（試験体群 A）のヤング係数及び曲げ強度 を各々、乾燥時ヤング係数、乾燥時曲げ強度と定義し、温度を $\mathrm{t}$ と して $\mathrm{E}_{\mathrm{d}, \mathrm{t} 、} 、 \mathrm{~B}_{\mathrm{d}, \mathrm{t}}$ で表す。常温での $\mathrm{E}_{\mathrm{d}, \mathrm{t}} 、 \mathrm{~B}_{\mathrm{d}, \mathrm{t}}$ を $\mathrm{t}=\mathrm{a}$ として $\mathrm{E}_{\mathrm{d}, \mathrm{a} 、} \mathrm{~B}_{\mathrm{d}, \mathrm{a}}$ と表すと、既報 8)で示した温度 $\mathrm{t}$ における破壊試験によるヤング係 数残存率、曲げ強度残存率は、各々、 $\mathrm{R}_{\mathrm{Ed}}(\mathrm{t})=\mathrm{E}_{\mathrm{d}, \mathrm{t}} / \mathrm{E}_{\mathrm{d}, \mathrm{a}} 、 \mathrm{R}_{\mathrm{Bd}}(\mathrm{t})=\mathrm{B}_{\mathrm{d}, \mathrm{t}} / \mathrm{B}_{\mathrm{d}, \mathrm{a}}$ となる。次に、温度 $\mathrm{t}$ 、含水率 $\mathrm{W}$ の時のヤング係数、曲げ強度を各々、

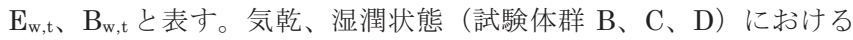
ヤング係数残存率、曲げ強度残存率は、各々、 $\mathrm{R}_{\mathrm{Ew}}(\mathrm{t})=\mathrm{E}_{\mathrm{w}, \mathrm{t}} / \mathrm{E}_{\mathrm{w}, \mathrm{a}}$ 、 $\mathrm{R}_{\mathrm{Bw}}(\mathrm{t})=\mathrm{B}_{\mathrm{w}, \mathrm{t}} / \mathrm{B}_{\mathrm{w}, \mathrm{a}}$ となる。また当該温度において含水率が力学的性能 に及ぼす影響を $\mathrm{R}_{\mathrm{Et}}(\mathrm{w})=\mathrm{E}_{\mathrm{w}, \mathrm{t}} / \mathrm{E}_{\mathrm{d}, \mathrm{t}} 、 \mathrm{R}_{\mathrm{Bt}}(\mathrm{w})=\mathrm{B}_{\mathrm{w}, \mathrm{t}} / \mathrm{B}_{\mathrm{d}, \mathrm{t}}$ で表し、以下、各々、 温度 $\mathrm{t}$ における含水時ヤング係数比、含水時曲げ強度比という。

ヤング係数は非破壊で測定可能なため、 $\mathrm{E}_{\mathrm{d}, \mathrm{t}}$ と $\mathrm{E}_{\mathrm{d}, \mathrm{a}} 、 \mathrm{E}_{\mathrm{w}, \mathrm{t}}$ と $\mathrm{E}_{\mathrm{w}, \mathrm{a}}$ は同じ試験体について把握でき、ヤング係数残存率 $\mathrm{R}_{\mathrm{Ed}}(\mathrm{t}) 、 \mathrm{R}_{\mathrm{Ew}}(\mathrm{t})$ も試験体ごとに算定可能である。この残存率は常温時の非破壊試験 での測定値を基準とし、常温時の残存率は、破壊試験の值を非破壊 試験の值で除した值とする。これに対し、曲げ強度は計測時に試験 体の破壊を伴うため、同一試験体にて含水率や温度の異なる場合の

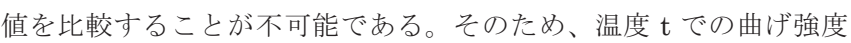
残存率 $\mathrm{R}_{\mathrm{Bd}}(\mathrm{t}) 、 \mathrm{R}_{\mathrm{Bw}}(\mathrm{t})$ は、各条件での試験体群の平均値を用い算出 した。また、含水率 $\mathrm{W}$ での含水時ヤング係数比 $\mathrm{R}_{\mathrm{Et}}(\mathrm{w})$ 及び含水時 曲げ強度比 $\mathrm{R}_{\mathrm{Bt}}(\mathrm{w})$ についても試験体群の平均值を用いて算出した。

\section{3. 実験概要}

\section{3-1. 試験体の条件}

実験に用いた無欠点小試験体 (以後、試験体) の概要図を図 1 に、 試験体条件及び本数を表 1 に示寸。試験体には、寸法 $20 \mathrm{~mm}$ $\times 20 \mathrm{~mm} \times 320 \mathrm{~mm} 、 2$ 方柾、無欠点の木片を使用した。スギの試験体 は、含水率が繊維飽和点よりも十分に高い丸太及び気乾状態に乾燥 させた丸太から、ケヤキは、含水率が繊維飽和点よりも十分に高い 丸太及び気乾状態に乾燥させた板材から切り出し製作した。試験体 の含水率調整は、試験体群 $\mathrm{A}$ （含水率 $5 \%$ 以下）及び $\mathrm{B}$ （含水率 5 〜 15\%）は $60^{\circ} \mathrm{C}$ の恒温炉により、試験体群 $\mathrm{C}$ (含水率 15３0\%) 及び D (含水率 $30 \%$ 超) は養生室(温度 $20^{\circ} \mathrm{C} ・$ 相対湿度 $40 \%$ )での
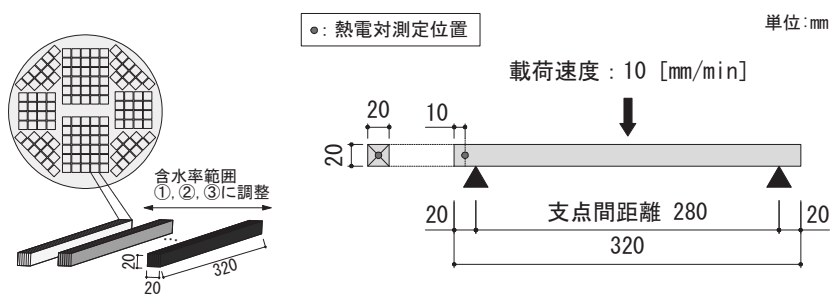

図 1 試験体概要図
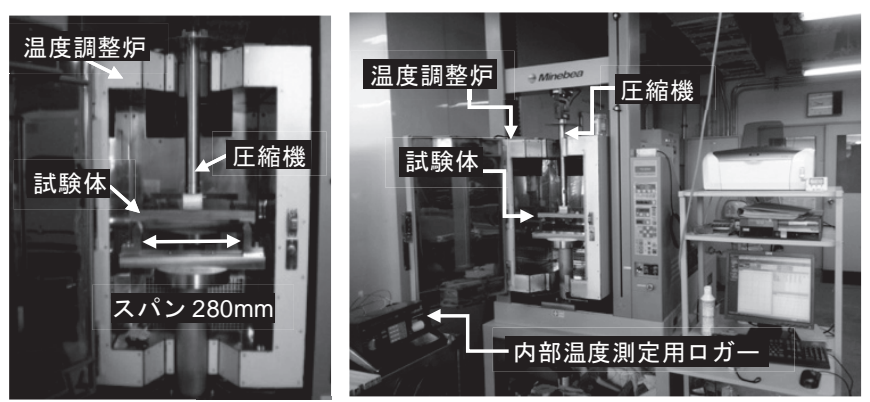

写真 1 温度調整炉付き圧縮試験機 
自然乾燥により各含水率範囲を目標に行った。また破壊試験時の含 水率は、実験終了後に全乾法により算定した。実験に供せられる試 験体数はこれらの条件の制約を受ける。なお、試験体の全乾密度 (平

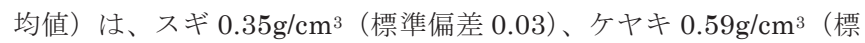
準偏差 0.06) である。

\section{3-2. 実験方法}

曲げ試験は JIS Z 2101「木材の曲げ試験方法」に準拠し、支持間 隔 $280 \mathrm{~mm}$ の 3 点曲げ試験として、試験装置には温度調整炉付きの 圧縮試験機（ミネベア・テクノグラフ TG-50kN）を使用した（写 真 1)。実験の手順を図 2 に示す。まず、前述（3-1）に示した方法
により試験体の含水率調整を行った。更にそれぞれの試験体群にお いて、a〜d の 4 グループ (a. 常温 $\left(20^{\circ} \mathrm{C}\right) 、$ b $\left..50^{\circ} \mathrm{C} 、 \mathrm{c} .80^{\circ} \mathrm{C} 、 \mathrm{~d} .95^{\circ} \mathrm{C}\right)$ に分けた後、常温下で強度が低下しない範囲（既報 ${ }^{8}$ ) にならい、ス ギ $0.25 \mathrm{kN}$ 、ケヤキ $0.5 \mathrm{kN}$ ）で加力する非破壊試験を行い、全試験 体の常温時ヤング係数を把握した。その後、各温度下において試験 体が破断に至るまで加力する破壊試験を行った。非破壞試験、破壞 試験ともに載荷位置はスパンの中央部とし、載荷速度が $10 \mathrm{~mm} /$ 分と なるように載荷した。a グループは破壊試験を常温で行い、常温時 のヤング係数及び曲げ強度を算出し、 $\mathrm{b} \sim \mathrm{d}$ のグループは、試験体内 部及び雾囲気温度が所定の温度に達するのを確認した後、高温のま

表 1 試験体条件及び本数一覧

\begin{tabular}{|c|c|c|c|c|c|c|c|c|c|c|c|c|c|c|c|c|c|c|c|c|c|}
\hline \multicolumn{2}{|c|}{ 含水率W } & \multicolumn{5}{|c|}{ 試験体群A W $\leqq 5 \%$} & \multicolumn{5}{|c|}{ 試験体群B $5 \%<\mathrm{W} \leqq 15 \%$} & \multicolumn{5}{|c|}{ 試験体群C $15 \%<W \leqq 30 \%$} & \multicolumn{5}{|c|}{ 試験体群D W>30\% } \\
\hline \multirow[b]{2}{*}{\begin{tabular}{|l|l} 
樹 \\
種
\end{tabular}} & \multirow[b]{2}{*}{ 温度 } & \multirow{2}{*}{$\begin{array}{l}\text { 試験 } \\
\text { 体数 } \\
\text { [本 }]\end{array}$} & \multicolumn{2}{|c|}{ 含水率 $*$ [\%] } & \multirow{2}{*}{$\begin{array}{c}\text { ヤング係数** } \\
\text { (平均) } \\
{\left[\mathrm{N} / \mathrm{mm}^{2}\right]}\end{array}$} & \multirow[b]{2}{*}{$\begin{array}{l}\text { 標集偏差 } \\
\text { (ヤング伱数) }\end{array}$} & \multirow{2}{*}{ 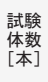 } & \multicolumn{2}{|c|}{ 含水率* [\%] } & \multirow{2}{*}{$\begin{array}{c}\text { ヤング係数** } \\
\text { (平均) } \\
{\left[\mathrm{N} / \mathrm{mm}^{2}\right]}\end{array}$} & \multirow{2}{*}{$\begin{array}{c}\text { 標準偏差 } \\
\text { (ヤング数) }\end{array}$} & \multirow{2}{*}{$\begin{array}{l}\text { 試験 } \\
\text { 体数 } \\
\text { [本] }\end{array}$} & \multicolumn{2}{|c|}{ 含水率* [\%] } & \multirow{2}{*}{$\begin{array}{c}\text { ヤング係数** } \\
\text { (平均) } \\
{\left[\mathrm{N} / \mathrm{mm}^{2}\right]}\end{array}$} & \multirow[b]{2}{*}{$\begin{array}{l}\text { 標隻偏差 } \\
\text { (ヤング係数) }\end{array}$} & \multirow{2}{*}{ 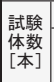 } & \multicolumn{2}{|c|}{ 含水率 $\%$ [\%] } & \multirow{2}{*}{$\begin{array}{c}\text { ヤング係数** } \\
\text { (平均) } \\
{\left[\mathrm{N} / \mathrm{mm}^{2}\right]}\end{array}$} & \multirow[b]{2}{*}{$\begin{array}{c}\text { 標準偏差 } \\
\text { (ヤング係数 }\end{array}$} \\
\hline & & & 平均 & $\begin{array}{l}\text { 最大 } \\
\text { 最小 }\end{array}$ & & & & 平均 & $\begin{array}{l}\text { 最大 } \\
\text { 最小 }\end{array}$ & & & & 平均 & $\begin{array}{l}\text { 最大 } \\
\text { 最小 }\end{array}$ & & & & 平均 & $\begin{array}{l}\text { 最大 } \\
\text { 最小 }\end{array}$ & & \\
\hline \multirow{7}{*}{$\begin{array}{l}\text { 原 } \\
\text { ギ }\end{array}$} & \multirow{2}{*}{ 常温 } & \multirow{2}{*}{14} & \multirow{2}{*}{4.92} & 5.22 & \multirow{2}{*}{8014} & \multirow[b]{2}{*}{1682} & \multirow{2}{*}{16} & & 14.00 & & & & & 29.76 & & & & & 151.84 & & \\
\hline & & & & 4.55 & & & & 13.00 & 7.20 & 8252 & $14 / 5$ & 11 & 23.49 & 18.67 & 1611 & 546 & 18 & 89.96 & \begin{tabular}{|l|}
32.71 \\
\end{tabular} & 1640 & 1240 \\
\hline & $50^{\circ} \mathrm{C}$ & 15 & 4.73 & 5.04 & 8267 & 1320 & 15 & 13.06 & 13.58 & 7714 & 1059 & 13 & 22.23 & 30.10 & 7321 & 842 & 17 & 91.62 & 160.91 & 7083 & 951 \\
\hline & & & & 4.37 & 0201 & $10<0$ & 10 & 10.00 & 12.60 & 1714 & 1005 & 100 & & 16.71 & 1021 & 042 & 11 & 91.02 & 37.00 & & 901 \\
\hline & $80^{\circ} \mathrm{C}$ & 15 & 3.66 & 4.04 & 8538 & 1303 & 15 & 12.81 & 13.42 & 7436 & 1089 & 14 & 23.85 & 30.38 & 7577 & 921 & 16 & 97.17 & 180.52 & 7327 & 956 \\
\hline & .000 & 10 & 0.00 & 2.62 & 0000 & 1000 & 10 & (2).01 & 12.32 & 1400 & 1000 & 14 & 20.00 & 19.62 & 19דו & रा & 10 & (5) & 33.50 & tori & 00 \\
\hline & $95^{\circ} \mathrm{C}$ & 15 & 3.31 & $\begin{array}{l}3.75 \\
2.62\end{array}$ & 8274 & 1555 & 17 & 12.59 & $\begin{array}{l}14.14 \\
11.87\end{array}$ & 7199 & 1108 & 10 & 22.21 & $\begin{array}{l}29.49 \\
16.30\end{array}$ & 7453 & 774 & 18 & 90.88 & \begin{tabular}{|c|}
146.77 \\
34.12 \\
\end{tabular} & 5916 & 875 \\
\hline & 常温 & 15 & 2.13 & 2.72 & 7792 & 543 & 21 & 10.93 & 15.43 & 8557 & 834 & 20 & 19.02 & 23.92 & 8251 & 664 & 19 & 76.26 & 92.70 & 8791 & 1121 \\
\hline & & 10 & 2.13 & 1.79 & $1 / 92$ & 543 & 21 & 10.93 & 8.45 & 8501 & 834 & 20 & 19.02 & 16.00 & 8251 & 604 & 19 & 10.20 & 32.81 & $8 / 91$ & 1121 \\
\hline & $50^{\circ} \mathrm{C}$ & 15 & 2.01 & 2.43 & 7861 & 817 & 15 & 9.57 & 14.65 & 7930 & 862 & 24 & 18.85 & 29.76 & 7817 & 1152 & 17 & 82.57 & 93.74 & 8330 & 803 \\
\hline$t$ & & & & 1.64 & & & & & 8.41 & & & & & 15.70 & & & & & 42.78 & & \\
\hline | & $80^{\circ} \mathrm{C}$ & 15 & 2.02 & 2.45 & 7878 & 434 & 13 & 8.95 & 15.21 & 7887 & 845 & 23 & 18.35 & 30.07 & 7715 & 1041 & \begin{tabular}{|l|}
21 \\
\end{tabular} & 72.92 & 92.64 & 8032 & 1231 \\
\hline & & & & 2.83 & & & & & $\frac{1.91}{1527}$ & & & & & \begin{tabular}{|l|}
15.46 \\
21.37
\end{tabular} & & & & & \begin{tabular}{|l|}
32.15 \\
95.32
\end{tabular} & & \\
\hline & $95^{\circ} \mathrm{C}$ & 15 & 1.80 & 1.53 & 7809 & 920 & 19 & 10.8 & 7.60 & 8070 & 660 & 15 & 17.39 & $\begin{array}{l}21.31 \\
15.56\end{array}$ & 7806 & 830 & 21 & 69.14 & 30.65 & 8281 & 1065 \\
\hline
\end{tabular}

※破壊試験終了後に全乾法により算定した無欠点小試験体の含水率(小数点以下は四捨五入とする)

※※非破壊試験により測定した無欠点小試験体の常温時ヤング係数の平均値

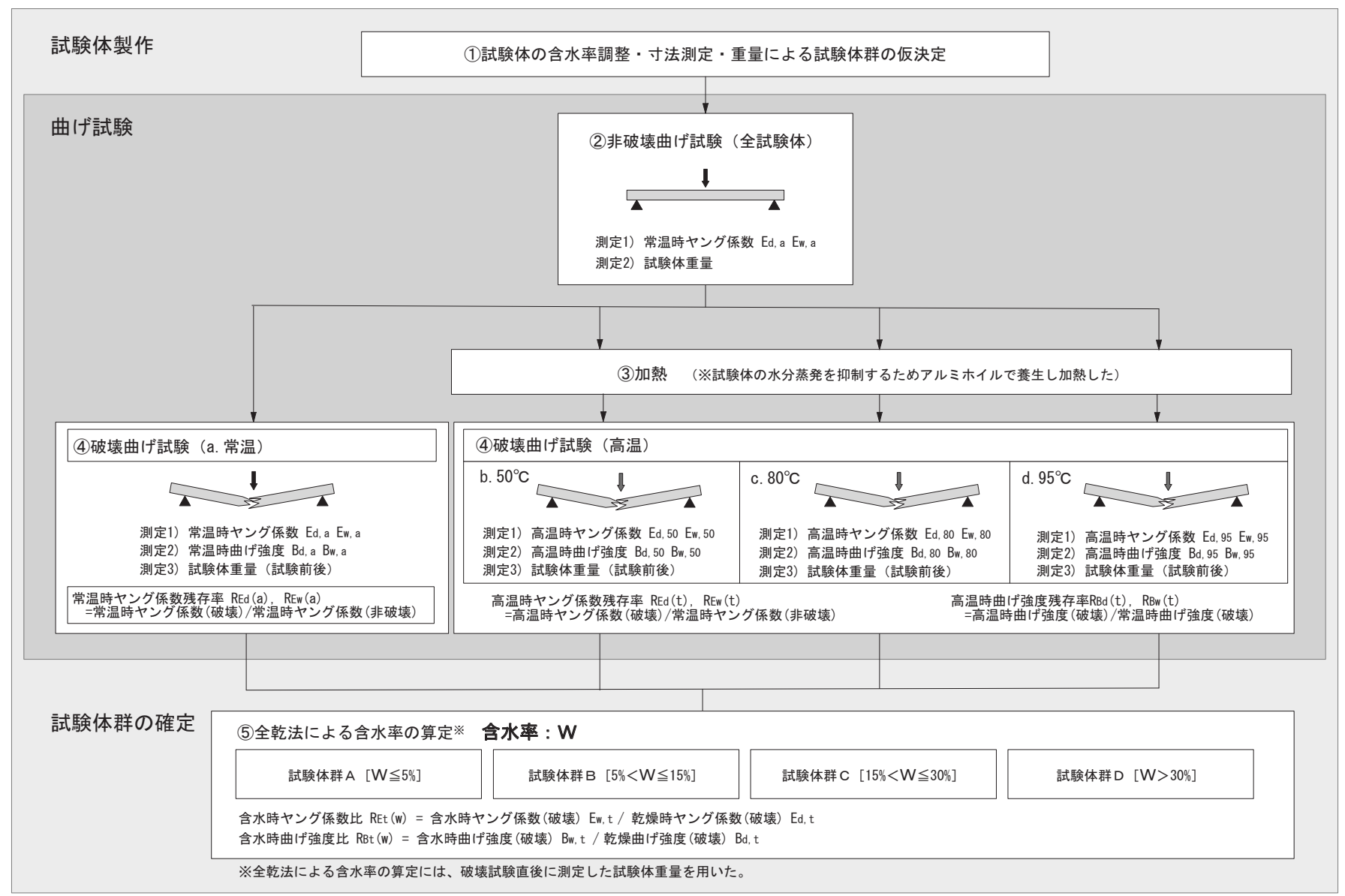

図 2 検討方法及び実験の手順 
ま破壊試験を行い、高温時ヤング係数及び曲げ強度を算出した。

なお、本実験はJIS の試験方法にならい、ヤング係数は、せん断 変形の影響は考慮しない式（1）より、曲げ強度は式（2）より算定 した。（1）式では、2 章で述べたヤング係数残存率算定のため、荷 重変形関係より比例域の範囲を確認した上で、非破壊試験、破壊試 験ともに、比例域の荷重の上限を $0.2 \mathrm{kN}$ 、下限を $0.1 \mathrm{kN}$ と設定した。 本実験の樹種ごとの荷重変形関係の典型例を図 3,4 に示寸。ただし、 弾性限界の荷重が $0.2 \mathrm{kN}$ より小さい $95^{\circ} \mathrm{C}$ におけるスギ試験体群 $\mathrm{D}$ の破壞試験のみ、試験力を $0.05 \sim 0.1 \mathrm{kN}$ としヤング係数を算定した。 また、試験実施時の試験体の寸法誤差が $0.3 \%$ ぼであったことから、 断面寸法は $20 \mathrm{~mm} \times 20 \mathrm{~mm}$ と設定した。

$$
\text { ヤング係数 } \mathrm{E}\left[\mathrm{N} / \mathrm{mm}^{2}\right]=\frac{\mathrm{L}^{3} \times \Delta \mathrm{P}}{48 \times \mathrm{I} \times \Delta \mathrm{S}}
$$

$\mathrm{L}$ : 支持点間距離, $\Delta \mathrm{P}$ : 比例域の上限荷重と下限荷重の差,

$$
\mathrm{I}: \text { 断面 } 2 \text { 次モーメント, } \Delta \mathrm{S}: \text { 変位量 }
$$

曲げ強度 $\mathrm{B}\left[\mathrm{N} / \mathrm{mm}^{2}\right]=\frac{\mathrm{P}_{\max } \times \mathrm{L}}{4 \times \mathrm{Z}}$

$\mathrm{P}_{\text {max }}$ : 最大荷重, $\mathrm{L}$ : 支持点間距離, $\mathrm{Z}$ : 断面係数 $=\mathrm{bh}^{2} / 6$ 試験体の内部温度は、試験体の力学的性能に影響しない支持点の 外側にシース熱電対 $\phi 1 \mathrm{~mm}$ を設置し測定した（図 1)。試験体の内 部温度の計測にあたっては、予め試験体と同形状の木片を用いてシ 一ス熱電対 $\phi 1 \mathrm{~mm}$ により木口近傍及び中央部での内部温度を測定 して、加熱に伴う温度変化に大きな差異がないことを確認し、内部 温度の測定位置を決定した。破壊試験では、材内が所定の温度に達 するまでにおよそ 30 分から 1 時間の時間を要した。また、破壊試

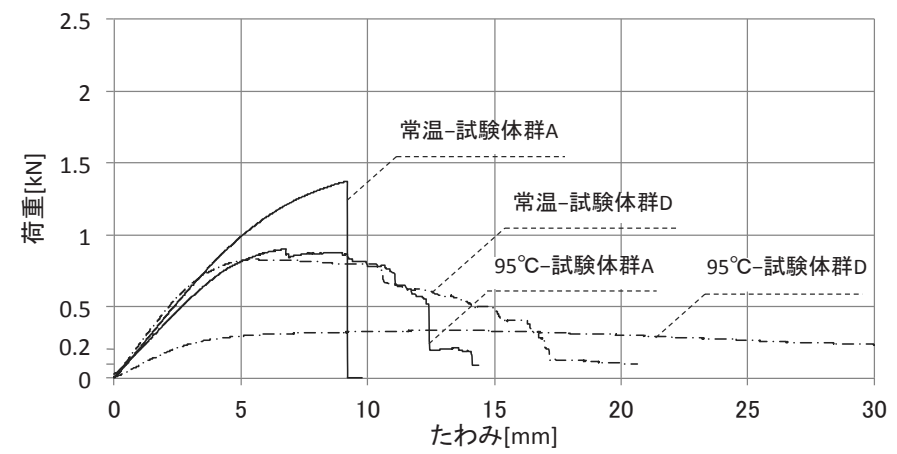

図 3 荷重変形の典型例（スギ）
験のために加熱する試験体は、材内の水分蒸発を抑制するため、ア ルミホイル（厚さ $20 \mu \mathrm{m} ）$ で養生した。その際、両面テープ等での 固定はせず、試験体へ巻くアルミホイルの大きさは必要最小限とし ており、アルミホイルの有無による測定值への影響は、試験機の計 測精度や木材の物性のばらつきに比べ小さく、破壊試験への影響は ないものと考える。試験時の含水率は、破壞試験終了後に、乾燥炉 $\left(105^{\circ} \mathrm{C}\right)$ により全ての試験体を全乾状態とし、式（3）により算出 した。これら算定した含水率に基づき、試験体群 $\mathrm{A} \sim \mathrm{D}$ を確定した。 なお、試験中の水分蒸発による重量減少は、スギで平均 $0.7 \%$ 、ケヤ キで平均 $0.5 \%$ あっあた。

$$
\text { 含水率 } \mathrm{W}[\%]=\frac{\mathrm{m}_{\mathrm{W}}-\mathrm{m}_{\mathrm{o}}}{\mathrm{m}_{\mathrm{o}}} \times 100
$$

$\mathrm{m}_{\mathrm{w}}$ : 含水率 $\mathrm{W}$ の時の重量, $\mathrm{m}_{0}$ : 全乾時の重量

\section{4. 結果及び考察}

\section{4-1. $100^{\circ} \mathrm{C}$ 未満における木材の力学的性能の含水率依存性}

各実験条件下での含水率及び破壊試験より算定したヤング係数、 曲げ強度に関する結果を表 2 と図 5〜8 に示す。図には、繊維飽和 点を $30 \%{ }^{1) \sim 3)}$ と仮定し、30\%を境として試験体群ごとに計測データ を対象とした回帰式及び相関係数 $\mathrm{r}$ を示す。二変数間の相関の強さ は、相関係数の絶対值 $|\mathrm{r}|$ が $0 \sim 0.2$ ではほとんど相関がない、 0.2 〜0.4 は弱い相関がある、0.4〜0.7 は比較的相関がある、0.7 1.0 は強い相関があると定義される。

\section{(1) ヤング係数}

含水率 $30 \%$ 以下の試験体群 $\mathrm{A} 、 \mathrm{~B} 、 \mathrm{C}$ では、スギ、ケヤキともに、

\begin{tabular}{|c|c|c|c|c|c|c|c|c|c|c|c|c|c|c|c|c|c|}
\hline \multirow{2}{*}{\multicolumn{2}{|c|}{$\begin{array}{c}\text { 樹種 } \\
\text { 実験条件 }\end{array}$}} & \multicolumn{8}{|c|}{ スギ } & \multicolumn{8}{|c|}{ ケヤキ } \\
\hline & & \multicolumn{4}{|c|}{ ヤング係数 } & \multicolumn{4}{|c|}{ 曲げ強度 } & \multicolumn{4}{|c|}{ ヤング係数 } & \multicolumn{4}{|c|}{ 曲げ強度 } \\
\hline 含水率 W & 温度 & $\begin{array}{c}\text { 実測值 }(\text { 平均 })^{*} \\
{\left[\mathrm{~N} / \mathrm{mm}^{2}\right]}\end{array}$ & $\begin{array}{c}\begin{array}{c}\text { 変動係数 } \\
{[\%]}\end{array} \\
\end{array}$ & 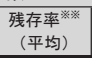 & 係数比** & $\begin{array}{c}\text { 実測値(平均) } \\
{\left[\mathrm{N} / \mathrm{mm}^{2}\right]}\end{array}$ & $\begin{array}{c}\text { 変動係数 } \\
{[\%]}\end{array}$ & 残存率** & 強度比 $*$ * & $\begin{array}{c}\text { 実測值 (平均) } \\
{\left[\mathrm{N} / \mathrm{mm}^{2}\right]}\end{array}$ & $\begin{array}{c}\text { 変動係数 } \\
{[\%]}\end{array}$ & $\begin{array}{c}\text { 残存率敩均 } \\
\text { (平均) }\end{array}$ & 係数比*棌 & $\begin{array}{c}\text { 実測值(平均) } \\
{\left[\mathrm{N} / \mathrm{mm}^{2}\right]}\end{array}$ & $\begin{array}{c}\text { 変動係数 } \\
{[\%]}\end{array}$ & 残存率:** & 強度比 $*$ * \\
\hline \multirow{4}{*}{$\begin{array}{c}W \leq 5 \% \\
\text { (試験体群A) }\end{array}$} & 常温 & 8137 & 1.34 & 1.02 & 1.00 & 72.67 & 19.00 & 1.00 & 1.00 & 7959 & 7.05 & 1.02 & 1.00 & 108.59 & 10.78 & 1.00 & 1.00 \\
\hline & $50^{\circ} \mathrm{C}$ & 7741 & 15.68 & 0.94 & 1.00 & 63.83 & 15.04 & 0.88 & 1.00 & 7627 & 11.41 & 1.01 & 1.00 & 100.69 & 12.51 & 0.98 & 1.00 \\
\hline & $80^{\circ} \mathrm{C}$ & 7754 & 15.19 & 0.91 & 1.00 & 49.80 & 15.46 & 0.67 & 1.00 & 7366 & 5.39 & 0.94 & 1.00 & 90.23 & 5.61 & 0.87 & 1.00 \\
\hline & $95^{\circ} \mathrm{C}$ & 7391 & 18.87 & 0.89 & 1.00 & 47.26 & 13.37 & 0.61 & 1.00 & 6975 & 12.14 & 0.89 & 1.00 & 81.90 & 11.72 & 0.81 & 1.00 \\
\hline \multirow{4}{*}{$\begin{array}{l}5 \%<\mathrm{W} \leqq 15 \% \\
\text { (試験体群B) }\end{array}$} & 常温 & 8313 & 17.78 & 1.01 & 1.02 & 63.88 & 16.61 & 1.00 & 0.88 & 8648 & 9.16 & 1.01 & 1.09 & 106.54 & 11.58 & 1.00 & 0.98 \\
\hline & $50^{\circ} \mathrm{C}$ & 7378 & 13.52 & 0.96 & 0.95 & 51.79 & 11.23 & 0.81 & 0.81 & 7349 & 10.28 & 0.93 & 0.96 & 85.02 & 10.74 & 0.84 & 0.84 \\
\hline & $80^{\circ} \mathrm{C}$ & 6276 & 23.19 & 0.84 & 0.81 & 36.87 & 13.19 & 0.63 & 0.74 & 6281 & 12.09 & 0.80 & 0.85 & 58.24 & 11.89 & 0.66 & 0.65 \\
\hline & $95^{\circ} \mathrm{C}$ & 5399 & 24.00 & 0.75 & 0.73 & 27.93 & 14.22 & 0.59 & 0.59 & 4457 & 42.90 & 0.55 & 0.64 & 40.52 & 24.82 & 0.58 & 0.49 \\
\hline \multirow{4}{*}{$\begin{array}{l}15 \%<W \leq 30 \% \\
\text { (試験体群C) }\end{array}$} & 常温 & 8048 & 9.70 & 1.06 & 0.99 & 49.04 & 8.47 & 1.00 & 0.67 & 8237 & 7.18 & 1.00 & 1.04 & 94.35 & 10.10 & 1.00 & 0.87 \\
\hline & $50^{\circ} \mathrm{C}$ & 7082 & 10.10 & 0.97 & 0.91 & 40.50 & 8.70 & 0.74 & 0.63 & 7074 & 14.97 & 0.91 & 0.93 & 66.06 & 10.24 & 0.65 & 0.66 \\
\hline & $80^{\circ} \mathrm{C}$ & 5721 & 12.22 & 0.76 & 0.74 & 25.68 & 12.76 & 0.52 & 0.52 & 3976 & 30.08 & 0.51 & 0.54 & 33.18 & 10.65 & 0.37 & 0.37 \\
\hline & $95^{\circ} \mathrm{C}$ & 4599 & 12.59 & 0.62 & 0.62 & 20.66 & 6.27 & 0.46 & 0.44 & 2760 & 34.08 & 0.35 & 0.40 & 27.33 & 7.49 & 0.35 & 0.33 \\
\hline \multirow{4}{*}{$\begin{array}{c}W>30 \% \\
\text { (試験体群D) }\end{array}$} & 常温 & 7736 & 16.63 & 1.01 & 0.95 & 43.98 & 11.96 & 1.00 & 0.61 & 8841 & 13.77 & 1.00 & 1.11 & 88.07 & 13.33 & 1.00 & 0.81 \\
\hline & $50^{\circ} \mathrm{C}$ & 6678 & 9.65 & 0.95 & 0.86 & 37.35 & 13.40 & 0.59 & 0.59 & 7283 & 11.78 & 0.88 & 0.95 & 58.58 & 7.43 & 0.49 & 0.58 \\
\hline & $80^{\circ} \mathrm{C}$ & 4831 & 14.81 & 0.66 & 0.62 & 23.02 & 13.53 & 0.44 & 0.46 & 3978 & 14.69 & 0.51 & 0.54 & 32.00 & 6.34 & 0.33 & 0.35 \\
\hline & $95^{\circ} \mathrm{C}$ & 3486 & 15.34 & 0.60 & 0.47 & 17.59 & 14.16 & 0.37 & 0.37 & 3578 & 32.19 & 0.43 & 0.51 & 32.19 & 28.71 & 0.39 & 0.39 \\
\hline
\end{tabular}

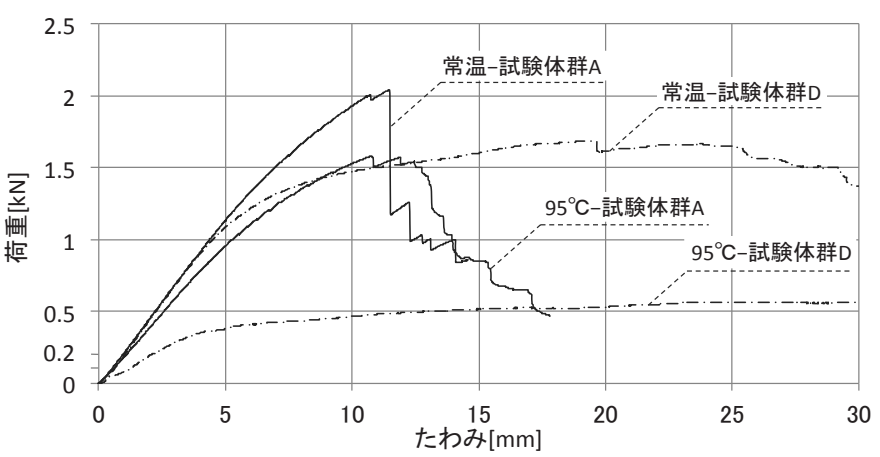

図 4 荷重変形の典型例（ケヤキ） 
常温及び $50^{\circ} \mathrm{C}$ に比べ、 $80^{\circ} \mathrm{C} 、 95^{\circ} \mathrm{C}$ の温度において相関係数 0.6 以上 と比較的相関を示し、含水率の増加に伴いヤング係数が低下した。 また常温時の木材の力学的性能の低下は、木材の細胞壁内の結合水 の量が増加することが大きな要因とされ 1),2)、繊維飽和点は、細胞 壁が結合水で飽和した状態を示す。本実験においても含水率が $30 \%$ を超える試験体群 D では、スギ、ケヤキともに、いずれの温度にお いても含水率の増加に伴いヤング係数が散布し、温度依存性はみら れるものの、含水率 $30 \%$ 以下と比べ含水率依存性は小さい結果とな った。試験体群 D の温度ごとにおけるヤング係数の平均值は、乾燥 時の試験体群 $\mathrm{A}$ の平均值を基準とした含水時ヤング係数比 $\mathrm{R}_{\mathrm{Et}}(\mathrm{w})$ で表される(表 2)。

\section{(2) 曲げ強度}

含水率 $30 \%$ 以下の試験体群 $\mathrm{A} 、 \mathrm{~B} 、 \mathrm{C}$ では、各温度下での曲げ強 度の低下の傾向は樹種により異なる結果となった。スギは、いずれ の温度においても相関係数 0.72 以上と強い相関を示し、含水率の 増加に伴い曲げ強度が低下した。各温度下での単位含水率あたりの 曲げ強度の変化率は-1.34 -1.20（ $\mathrm{N} / \mathrm{mm}^{2} / \% ）$ と温度に依らずほぼ 同等の含水率依存性を有する。一方ケヤキは、単位含水率あたりの 曲げ強度の変化率が、常温では-0.86 $\left(\mathrm{N} / \mathrm{mm}^{2} / \%\right)$ であるのに対し、 $95^{\circ} \mathrm{C}$ では-3.42（N/mm²\%） と温度が高くなるほど含水率依存性が 高まる結果となった。

また試験体群 D では、スギ、ケヤキどちらも $30 \%$ を超える含水

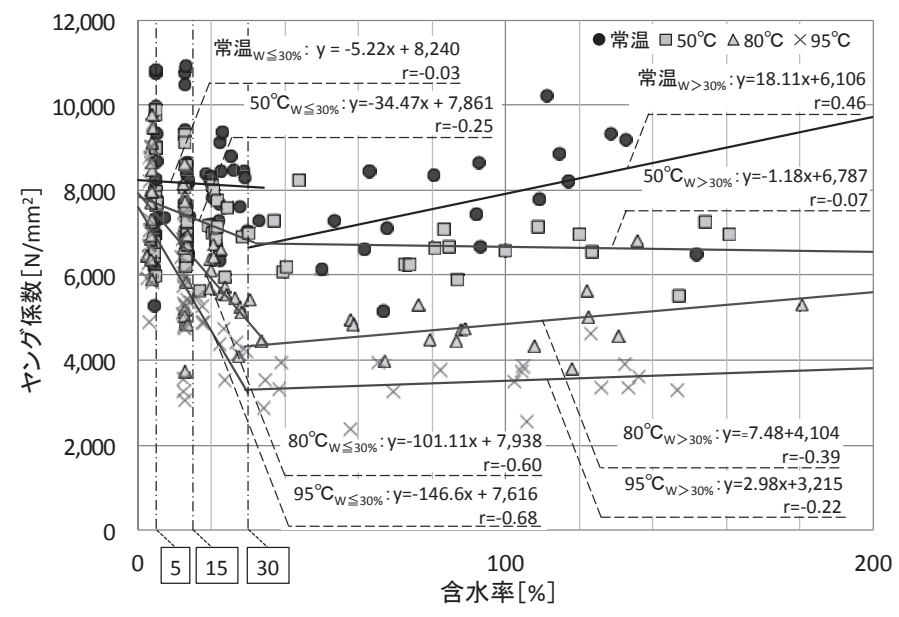

図 5 含水率とヤング係数 (スギ)

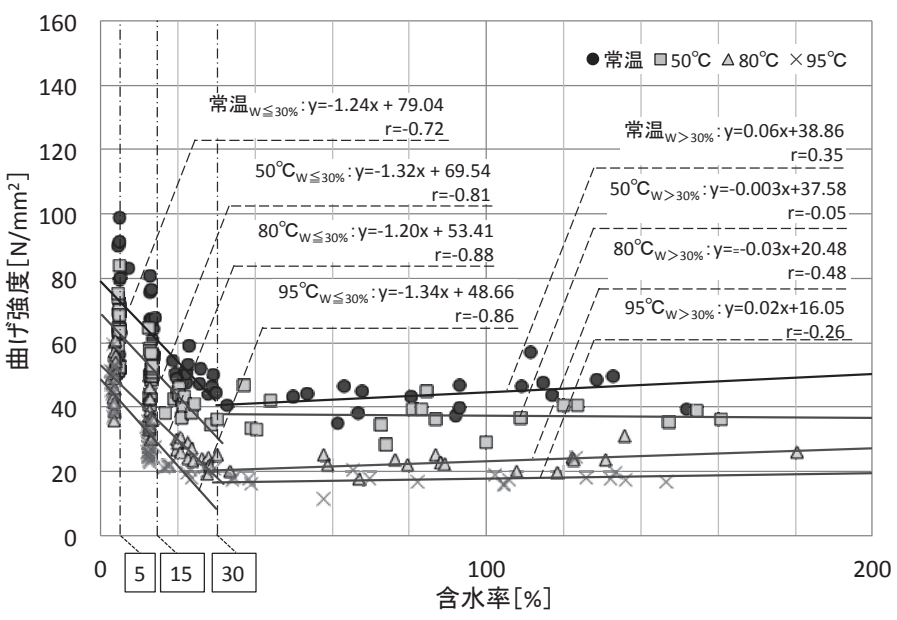

図 7 含水率と曲げ強度（スギ）
率の増加に伴い、曲げ強度の值が平均值の約 $\pm 10\left(\mathrm{~N} / \mathrm{mm}^{2}\right)$ の範囲 内に散布し、温度依存性はみられるものの、含水率依存性はみられ なかった。ただし、ケヤキの $80^{\circ} \mathrm{C}$ においては相関係数 0.67 と含水 率と曲げ強度に一定の相関がある結果となったが、 $95^{\circ} \mathrm{C}$ とほぼ同じ 範囲に分布しており、 $80^{\circ} \mathrm{C}$ 以上の温度では一定值に収束する傾向に あると考えられる。なお、試験体群 D の温度ごとにおける曲げ強度 の平均值は、乾燥時の試験体群 $\mathrm{A} の$ 平均值を基準とした曲げ強度比 $\mathrm{R}_{\mathrm{Bt}}(\mathrm{w})$ で表される（表 2 ）。これらの結果より、ヤング係数と同様、 曲げ強度においても $50^{\circ} \mathrm{C} \sim 95^{\circ} \mathrm{C}$ の温度下では、 $30 \%$ 付近を境に含水 率依存性は小さくなる結果となった。

\section{4-2．含水率が温度と力学的性能の関係へ及ぼす影響}

4-1 で述べた実験の結果を受け、2 章にて定義したヤング係数残存 率及び曲げ強度残存率をもとに、含水率が温度と力学的性能の関係 一及ぼす影響について考察する。

\section{(1) ヤング係数残存率}

温度とヤング係数残存率の関係を樹種別・試験体群ごとに表 $2 、$ 図 9,10 に示す。試験体群 $\mathrm{A}$ のヤング係数残存率への影響は、スギ とケヤキでは樹種を問わずほぼ一致した。 $95^{\circ} \mathrm{C}$ の高温時ヤング係数 残存率 $\mathrm{R}_{\mathrm{Ed}}(95)$ の平均值がスギで 0.89 、ケヤキで 0.82 となり、既往 研究 6) 8)で報告されている木材のヤング係数の温度依存性とほぼ一 致した。一方、試験体群 $\mathrm{B} 、 \mathrm{C} 、 \mathrm{D}$ では、常温から $50^{\circ} \mathrm{C}$ にかけて、 スギ、ケヤキともに温度に対するヤング係数の低下は約 2 割であり、

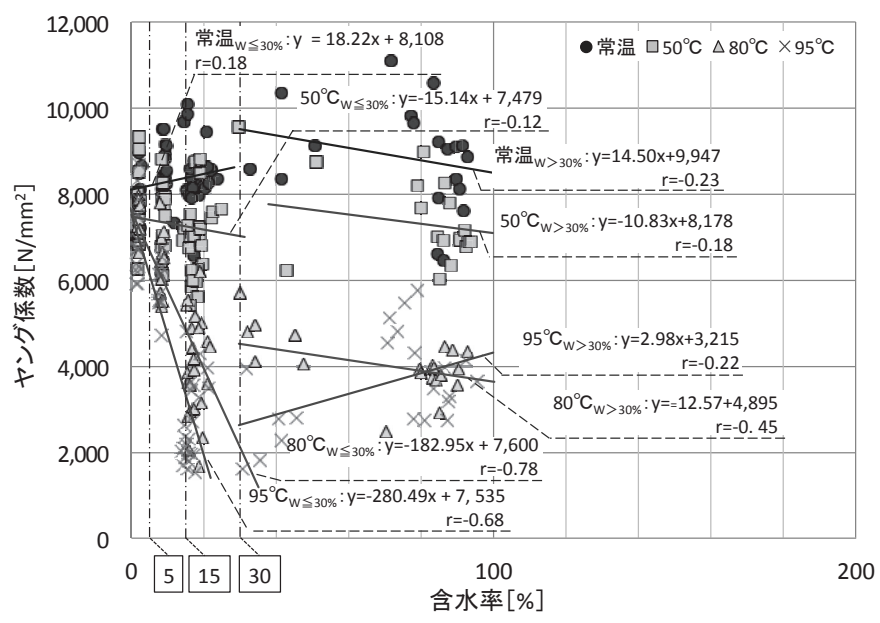

図 6 含水率とヤング係数（ケヤキ）

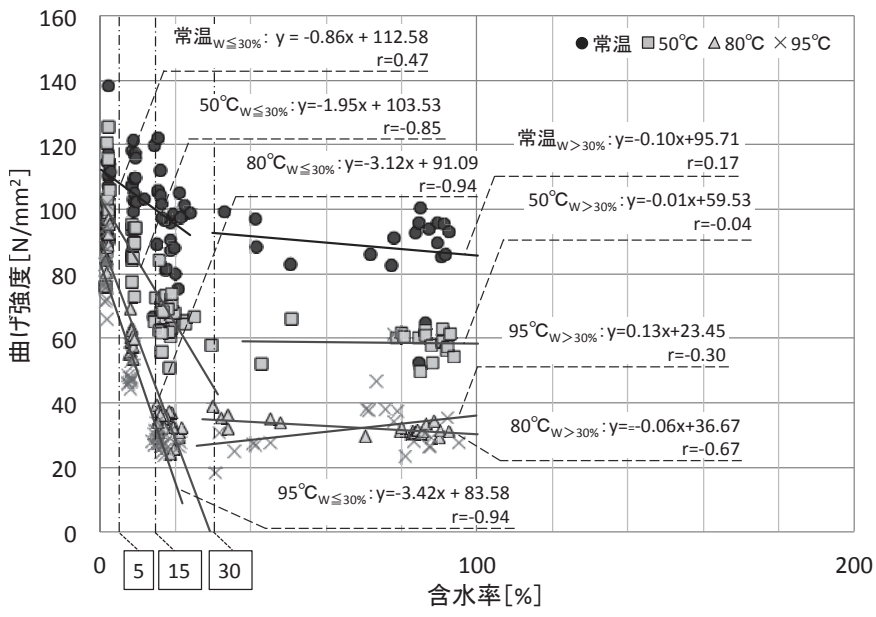

図 8 含水率と曲げ強度（ケヤキ） 
試験体群 $\mathrm{A}$ と同程度であるが、 $80^{\circ} \mathrm{C}$ 以上の温度では、スギとケヤキ で異なる傾向が夕られた。スギは試験体群の含水率が大きくなるに 伴い、高温時ヤング係数残存率 $\mathrm{R}_{\mathrm{Ew}}(\mathrm{t})$ の平均值が徐々に小さくなり、 $95^{\circ} \mathrm{C}$ ではいずれの試験体群においても平均值が 0.60 以上であった。 これに対しケヤキは温度に対する残存率の低下が比較的大きく、特 に含水率 $15 \%$ を超える試験体群 $\mathrm{C} 、 \mathrm{D}$ は、 $80^{\circ} \mathrm{C}$ 以上での残存率は平 均值が 0.51 以下と大きく低下した（表 2 、図 9,10）。

これらの結果から、 $50^{\circ} \mathrm{C}$ 以下の温度では、温度とヤング係数残存 率の関係へ及ぼす含水率の影響は小さいため、既報 8)で報告した乾 燥時のヤング係数の温度依存性により、スギ、ケヤキともに高温時 ヤング係数残存率 $\mathrm{R}_{\mathrm{Ew}}(\mathrm{t})$ を評価できると考えられる。しかし $80^{\circ} \mathrm{C}$ 以 上の温度では、ヤング係数残存率 $\mathrm{R}_{\mathrm{Ew}}(\mathrm{t})$ は温度及び含水率の双方の 変化に依存するため、乾燥時ヤング係数の温度依存性に加え、乾燥 時に対する含水時ヤング係数比 $\mathrm{R}_{\mathrm{Et}}(\mathrm{w})$ を考慮し評価する必要がある。 最高温度である $95^{\circ} \mathrm{C}$ での試験体群 $\mathrm{B} 、 \mathrm{C} 、 \mathrm{D}$ の係数比 $\mathrm{R}_{\mathrm{Et}}(\mathrm{w})$ は、ス ギで各々 $0.73 、 0.62 、 0.47$ 、ケヤキで $0.64 、 0.40 、 0.51$ と、含水時 ヤング係数は乾燥時ヤング係数よりも加熱による低下が大きい結果 となった（表 2)。

\section{(2) 曲げ強度残存率}

温度と曲げ強度残存率の関係を樹種別・試験体群ごとに表 2、図 11,12 に示す。なお、 2 章で述べたように、曲げ強度残存率は、曲

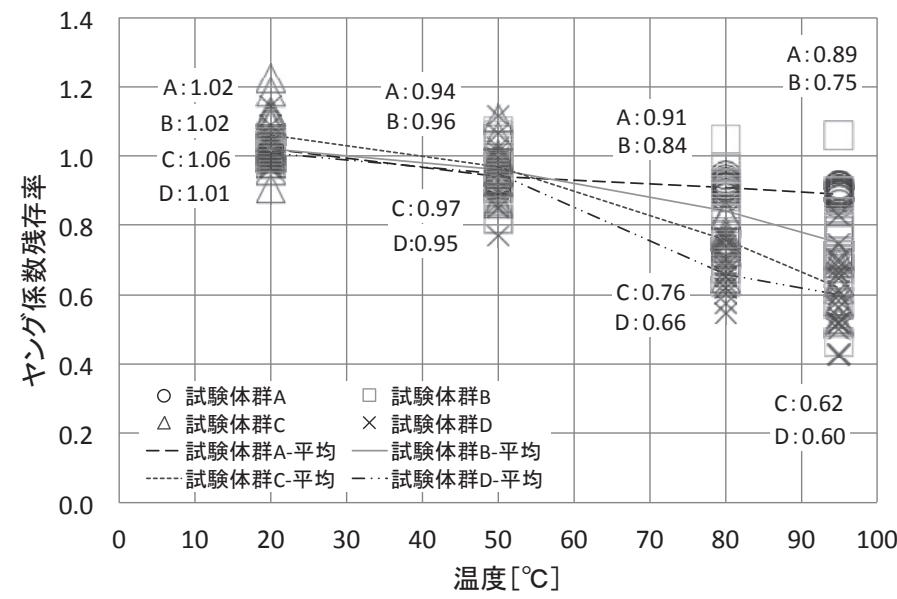

図 9 温度とヤング係数残存率（スギ）

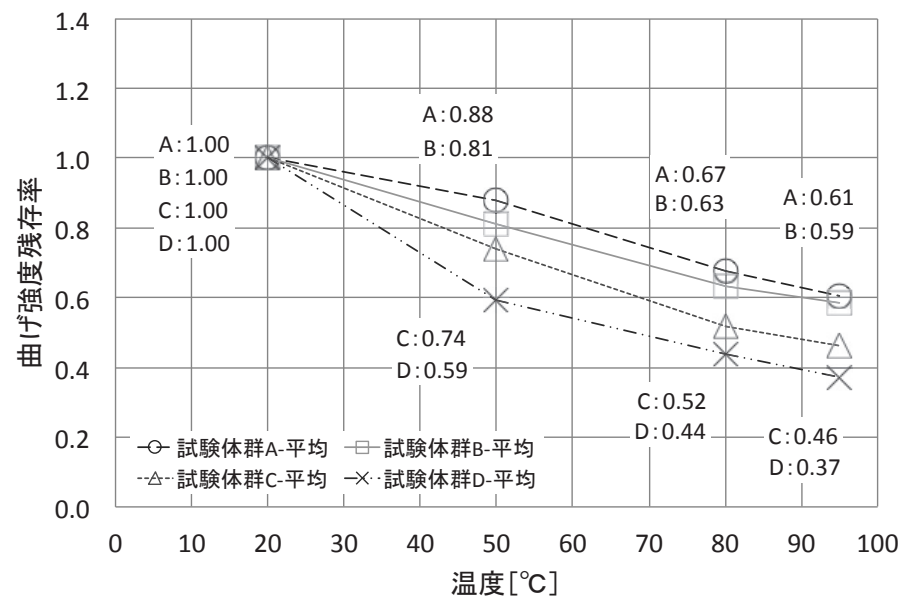

図 11 温度と曲げ強度残存率（スギ）
げ強度の值が破壊試験により算定されるため、常温で測定した試験 体群と高温で測定した試験体群の平均值の比として算定される。試 験体群 $\mathrm{A}$ においては、 $95^{\circ} \mathrm{C}$ での曲げ強度残存率 $\mathrm{R}_{\mathrm{Bd}}(95)$ がスギで 0.61 、ケヤキで 0.81 となり、スギ、ケヤキともに既往研究 7),8)の傾 向とおおよそ一致する。一方、試験体群 B、C、D では、スギとケ ヤキで異なる傾向がみられた。スギの試験体群 $\mathrm{B}$ は、温度上昇に伴 う曲げ強度の低下が試験体群 $\mathrm{A}$ とほぼ同程度であるが、試験体群 $\mathrm{C} 、$ $\mathrm{D}$ は、 $50^{\circ} \mathrm{C}$ での高温時曲げ強度残存率 $\mathrm{R}_{\mathrm{Bw}}(50)$ の平均值が各々 0.74 、 0.59 と、高温での低下が試験体群 A に比べて著しい。またケヤキは、 試験体群の含水率が大きくなるに伴い、高温時曲げ強度残存率が小 さくなり、含水時曲げ強度が乾燥時に比べ顕著に低下寸る結果とな った（表 2、図11,12）。

これらの結果から、スギの試験体群 B は、既報 8) で報告した乾 燥時曲げ強度の温度依存性により、高温時曲げ強度残存率 $\mathrm{R}_{\mathrm{Bw}}(\mathrm{t})$ を 評価できると考えられる。一方スギの試験体群 C、D、ケヤキ試験 体群 B、C、D では、含水時曲げ強度残存率が乾燥時に比べ顕著に 低下寸る。そのため、曲げ強度は温度及び含水率の双方の変化に依 存すると考えられ、乾燥時曲げ強度の温度依存性に加え、乾燥時に 対する含水時曲げ強度比 $\mathrm{R}_{\mathrm{Bt}}(\mathrm{w})$ を考慮し、その変化を評価する必要 がある。なお、最高温度である $95^{\circ} \mathrm{C}$ での試験体群 $\mathrm{C} 、 \mathrm{D}$ の強度比 $\mathrm{R}_{\mathrm{Bt}}(\mathrm{w})$ は、スギでは各々 $0.44 、 0.37$ 、ケヤキは $0.33 、 0.39$ と、含水

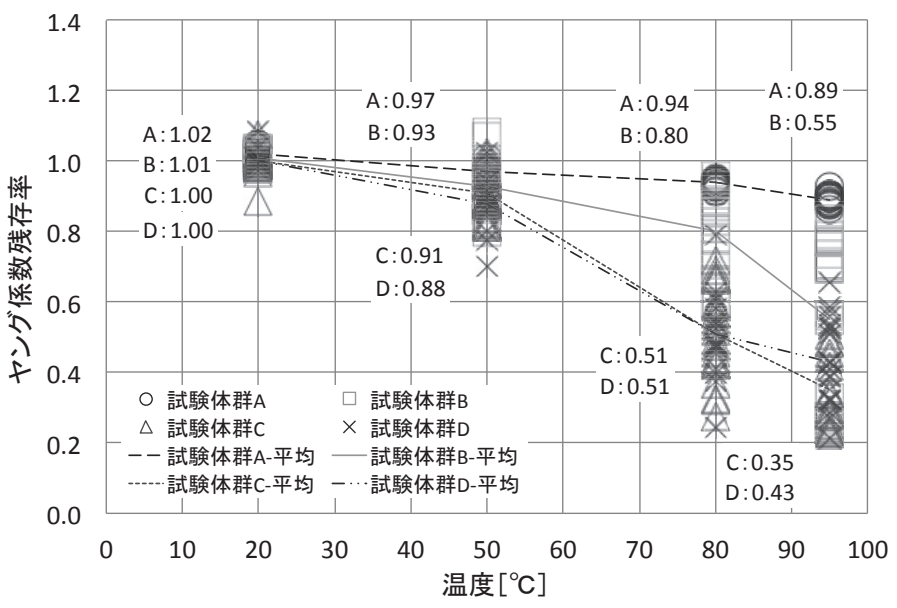

図 10 温度とヤング係数残存率(ケヤキ)

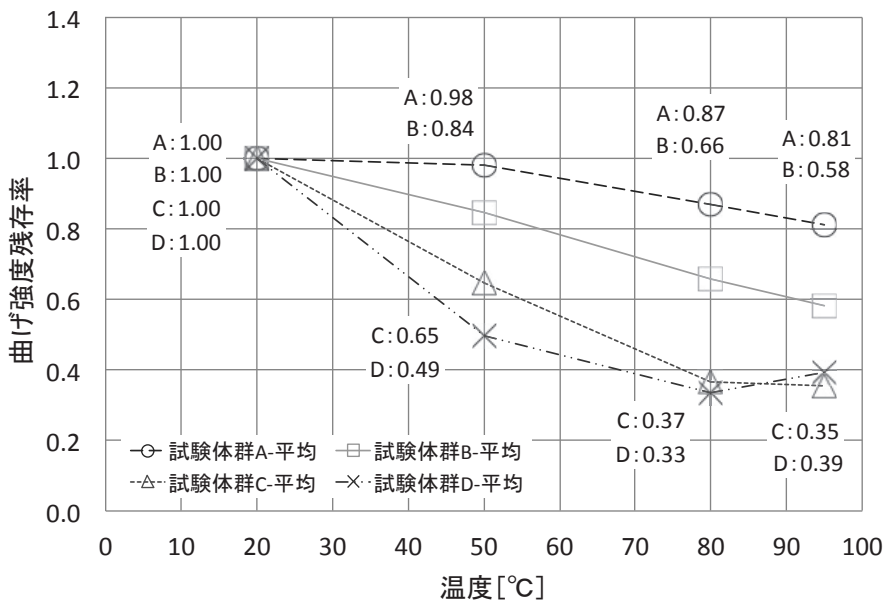

図 12 温度と曲げ強度残存率（ケヤキ） 
時曲げ強度は乾燥時曲げ強度よりも加熱による低下が大きい結果と なった（表 2)。

\section{4-3．曲げ強度とヤング係数の関係}

常温時の木材の曲げ強度については、樹種ごとに、密度やヤング 係数等との相関があるとの報告 $\left.\left.{ }^{1)}, 16\right), 17\right)$ がある。また曲げ強度は非破 壞での把握ができないため、木構造部材の品質管理上、火災時の曲 げ強度においても非破壊検査可能な諸量から推定できるようにする ことが望ましい。そこで、本実験における常温時及び高温時曲げ強 度について、破壊試験時のヤング係数との関係を考察する。図 13 〜 20 に試験体群 $\mathrm{A} \sim \mathrm{D}$ ごとの常温時及び高温時曲げ強度とヤング係 数との関係を示寸。図には実験条件ごとの回帰式及び相関係数 $\mathrm{r}$ を 示す。二変数間の相関の強さは前述（4-1）に示寸通りである。

図 13〜20によると、スギとケヤキでは異なる傾向を示寸結果と なった。スギの試験体群 $\mathrm{A}$ （含水率 $5 \%$ 以下）では、どの温度にお いてもヤング係数に依らず曲げ強度の值が散布し、相関係数も 0.32 以下であることから両者の相関は弱い結果となった。既報 8)では、 乾燥時スギのヤング係数と曲げ強度は、常温では相関係数が 0.78 、 $100^{\circ} \mathrm{C}$ では 0.77 と強い相関関係を示しているが、本研究では、ひと つの試験体群におけるヤング係数の散布範囲が既報よりも広く、同 程度の試験体数であっても相関の程度は異なる結果となった（図 13）。一方、試験体群 B、C、D（含水率 $5 \%$ 超）では、いずれの試 験体群においても、全ての温度でヤング係数の増加に伴い曲げ強度 も増加しており、相関係数も 0.51 以上と、相関または強い相関が認 められるため、ヤング係数による曲げ強度の予測に可能性があると 考えられる（図 15,17,19）。

これに対しケヤキは、試験体群 $\mathrm{A} 、 \mathrm{~B}$ （含水率 $15 \%$ 以下）及び $\mathrm{D}$ (含水率 $30 \%$ 超) においては、いずれの温度においても 0.57 以上の 相関係数となり、両者の間に相関または強い相関が認められ、ヤン グ係数による曲げ強度の予測に可能性があると考えられる（図 14,16,20）。しかし、試験体群 C（含水率 $15 \%$ 超 $30 \%$ 以下）では、 常温及び $50^{\circ} \mathrm{C}$ にいては、相関係数が 0.27 以下と小さく、曲げ強 度の予測に活用できるほどの傾向は見られなかった。また $80^{\circ} \mathrm{C}$ 以上 の温度では、ヤング係数に対する曲げ強度の増加は小さく、曲げ強 度が狭い範囲に分布する結果となった（図 18）。

\section{5. 総括}

$100^{\circ} \mathrm{C}$ 未満におけるスギ及びケヤキの無欠点小試験体を用いた曲 げ試験により、含水率が高温時の木材の力学的性能に及ぼす影響に 関し、以下の知見を得た。

（1） スギ、ケヤキともに含水率が $30 \%$ 以下の場合、 $50^{\circ} \mathrm{C}$ 以上の温 度下においても含水率の増加に伴いヤング係数が低下し、ま た温度が高くなるほど含水率に対するヤング係数の低下は大 きくなる。一方、含水率が $30 \%$ を超える場合は、ヤング係数 に及ぼす含水率の影響はみられない。

（2）常温から $50^{\circ} \mathrm{C}$ にかけて、スギ、ケヤキともに含水率が $5 \%$ を 超える試験体（以後、含水試験体）の温度に対するヤング係 数の低下は約 2 割であり、含水率が $5 \%$ 以下の試験体 (以後、 乾燥試験体）と同程度である。一方、 $80^{\circ} \mathrm{C}$ 以上の温度では、 高温時ヤング係数残存率は含水率に依存し、含水試験体は乾 燥試験体よりも残存率が小さい。
（3） スギは、含水率が $30 \%$ 以下の場合、含水率の増加に伴い曲げ 強度が低下し、いずれの温度においてもほぼ同等の含水率依 存性を有する。一方ケヤキは、温度が高くなるほど含水率に 対する曲げ強度の低下は大きくなる。含水率が $30 \%$ 以上の場 合は、スギ、ケヤキともに曲げ強度に及ぼす含水率の影響は みられない。

（4） スギの含水率が $15 \%$ 以下の場合、高温時曲げ強度残存率は乾 燥試験体と同程度である。一方、スギの含水率が $15 \%$ を超え る場合及びケヤキの含水試験体では、高温時曲げ強度残存率 は含水率に依存し、乾燥試験体よりも残存率が小さい。

（5） スギ、ケヤキともに、 $100^{\circ} \mathrm{C}$ 未満において含水率が力学的性 能の低下の要因となり、含水率の増加に伴い温度に対する低 下がより顕著となる。また、含水率 $30 \%$ 付近を境に力学的性 能の含水率依存性は異なる。

以上の知見により、火災加熱による木部材断面の力学的性能の低 下を予測・制御するためには、部材の含水率管理・把握が必要不可 欠である。また、含水率変化を伴う木構造部材の高温時力学的性能 の評価方法確立にあたっては、本報の実験結果に加え、火災加熱に 伴う木構造部材内部の水分移動の実態把握、更には含水率が炭化速 度へ及ぼす影響の把握が必要である。なお、本実験は無欠点小試験 体を用いて曲げ試験を実施しており、通常流通する構造用の木材は、 製材の場合、丸太の心材・辺材の別や節などの欠点の有無が考え得 るため、これら諸条件による影響についても、今後の検討課題とし たい。

\section{謝辞}

本実験は、科学研究費基盤研究「大断面木質部材の防耐火性能設 計の工学モデル」(代表研究者: 長谷見雄二) 及び公益財団法人 LIXIL 住生活財団の研究助成「火災加熱を受ける木部材の力学的性能予測 に関する研究」（採択者 : 加來千紘）により実施しました。試験体製 作には、株式会社亀山建設の亀山直央氏ならびに長尾大貴氏に多大 なるご尽力を頂きました。心からお礼申し上げます。また、研究を 進めるにあたりご協力頂きました皆様に、深く感謝申し上げます。

\section{参考文献}

1）岡野健、祖父江信夫 編：木材科学ハンドブック、朝倉書店、2006

2）伏谷賢美：木材の物理、文永堂出版、1985.9

3）渡辺治人：木材物理総論、農林出版株式会社、1978.3

4）森林総合研究所監修: 木材工業ハンドブック改訂 4 版、丸善、2004.3

5）安井昇、清水真理子、長谷見雄二、村上 雅英、上島 基英、木村忠 紀、北後 明彦、田村 佳英、吉田 正友、山本 幸一：柱圧縮試験によ る木造土壁の火災加熱時の非損傷性予測と木造土壁外壁の防火設計、 日本建築学会環境系論文集 第 574 号、pp.1-6、2003.12

6）保川みずほ、安井昇、鈴木あさ美、長谷見雄二、亀山直央、豊田康二、 門岡直也、上川大輔、腰原幹雄、小野徹郎：大断面広葉樹（ケヤキ） 製材による軸組柱の防耐火性能予測に関する研究、日本建築学会環境 系論文集 第 685 号、pp.633-638、2013.3

7）上杉三郎：スギ材の 180 C 以下加熱における曲げ性能、日本木材学会 誌 Vol.38、No.11、pp.985-994、1992.11

8）加來千紘、長谷見雄二、安井昇、保川みずほ、上川大輔、亀山直央、 小野徹郎、腰原幹雄、長尾博文: 火災加熱が木材の力学的性能に及ぼ す影響—加熱した針葉樹材及び広葉樹材の高温時及び加熱泠却後のヤ ング係数・曲げ強度の測定一、日本建築学会構造系論文集 701 号、 pp1065-1072、2014. 7

9）成瀬友宏、中村賢一、遊佐秀逸、増田秀昭、原田寿郎、山田誠、佐藤 


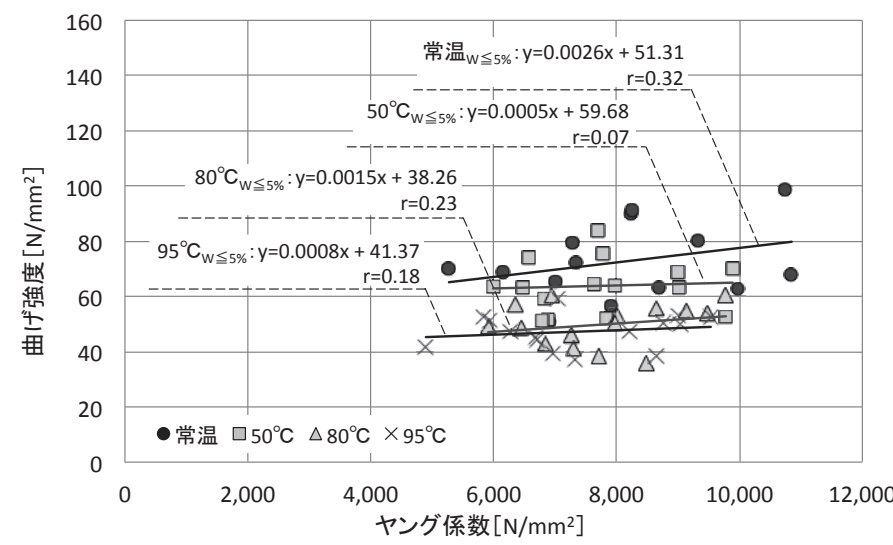

図 13 曲げ強度とヤング係数（スギ・含水率 $5 \%$ 以下）

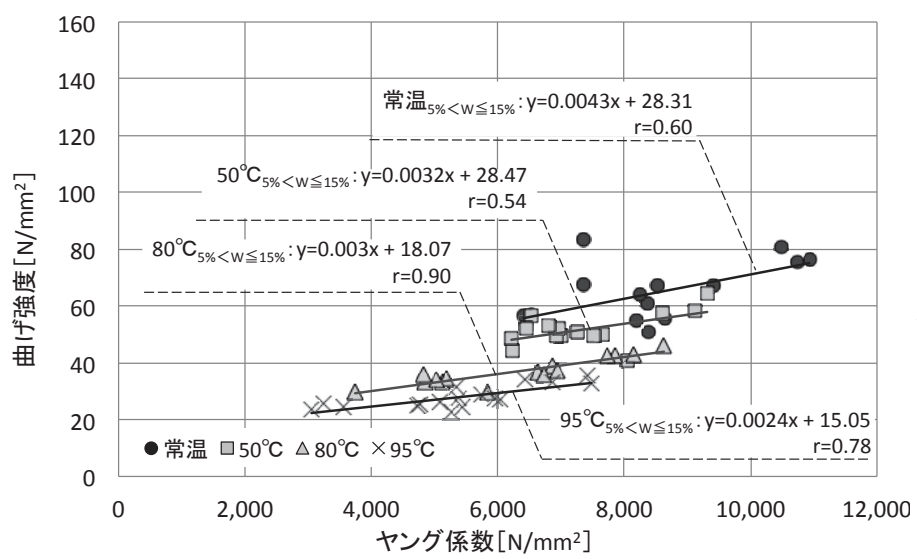

図 15 曲げ強度とヤング係数（スギ・含水率 $5 \%$ 超 15\%以下）

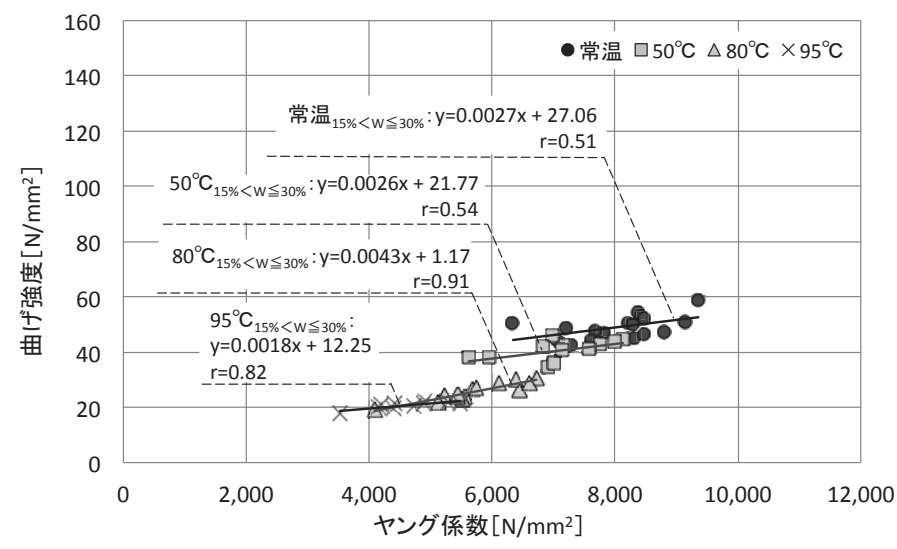

図 17 曲げ強度とヤング係数（スギ・含水率 $15 \%$ 超 30\%以下）

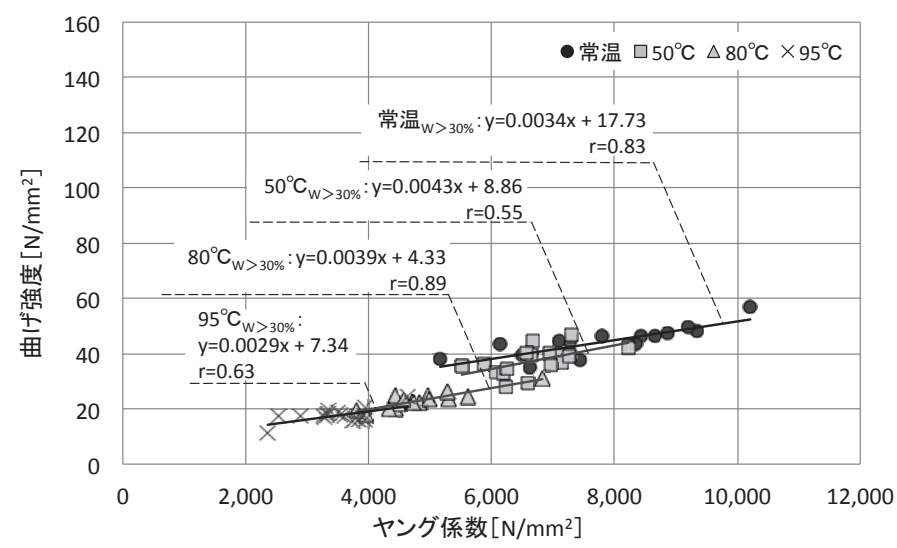

図 19 曲げ強度とヤング係数 (スギ·含水率 $30 \%$ 超)

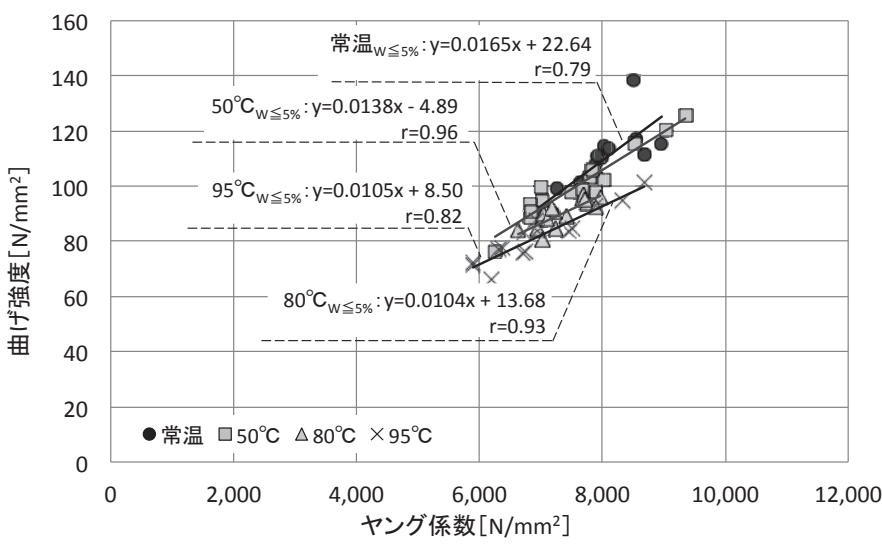

図 14 曲げ強度とヤング係数（ケヤキ・含水率 $5 \%$ 以下）

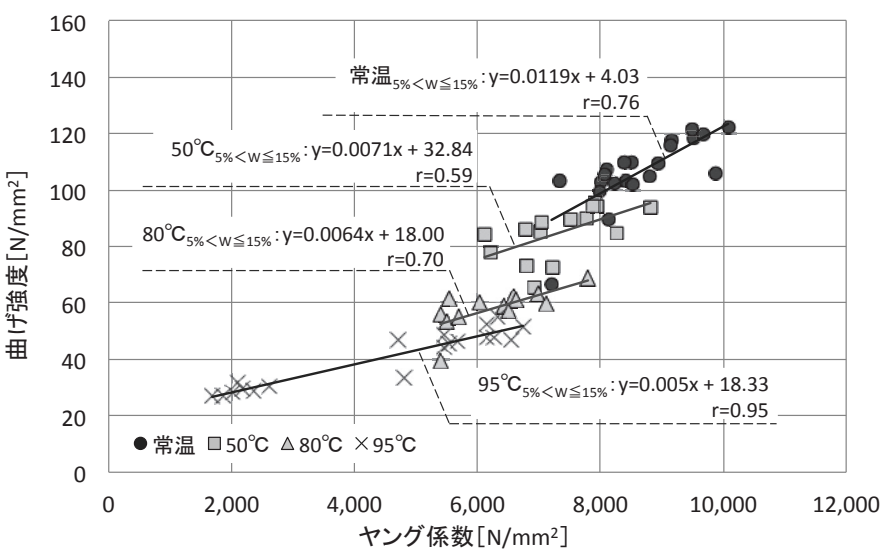

図 16 曲げ強度とヤング係数（ケヤキ・含水率 $5 \%$ 超 15\%以下）

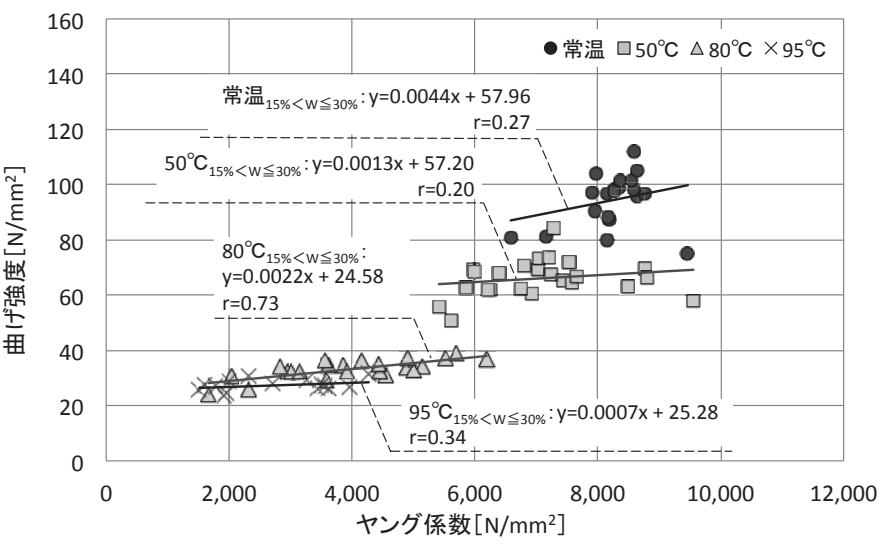

図 18 曲げ強度とヤング係数（ケヤキ・含水率 $15 \%$ 超 30\%以下）

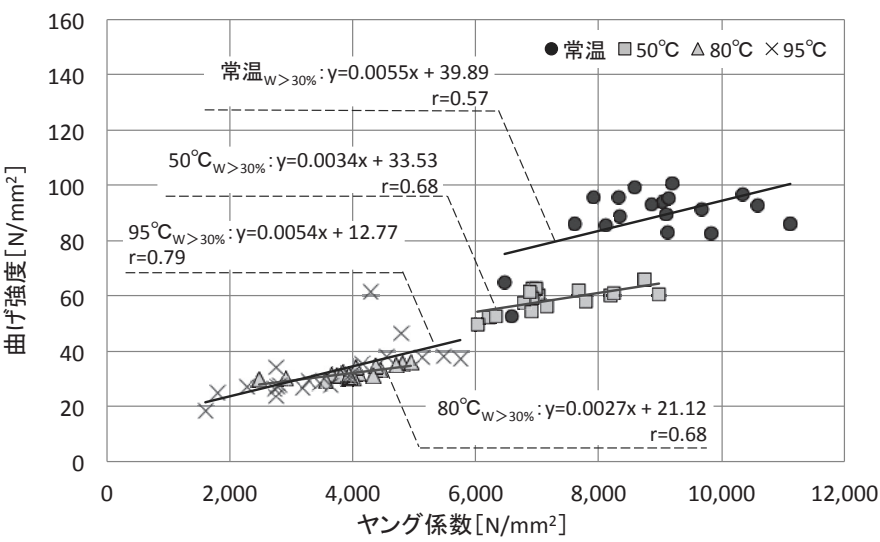

図 20 曲げ強度とヤング係数（ケヤキ・含水率 $30 \%$ 超） 
章: 構造用製材の耐火性能 その 1 , スギとカラマツの炭化速度、日本 建築学会大会学術講演梗概集、防火、pp.11-12、2004.8

10）斉藤春重、増田秀昭、中村賢一、成瀬友宏、遊佐秀逸、山田誠：構造 用製材の耐火性能 その 2 , 製材柱の載荷加熱実験、日本建築学会大会 学術講演梗概集、防火、pp.13-14、2004.8

11）山田誠、中村賢一、遊佐秀逸、成瀬友宏、増田秀昭、宮林正幸、佐藤 章: 構造用製材の耐火性能 その 3 , 柱、はりの載荷加熱実験、日本建 築学会大会学術講演梗概集、防火、pp.15-16、2004.8

12）保川みずほ、安井昇、鈴木あさ美、長谷見雄二、亀山直央、豊田康二、 門岡直也、腰原幹雄、小野徹郎、遊佐秀逸 : 大断面広葉樹（ケヤキ） 製材による寺院建築仕様軸組の防耐火性能一はり及び柱一はり接合部 の載荷加熱実験一、日本建築学会技術報告集 第 19 巻第 43 号、 pp.977-982、2013.10

13）清水真理子、長谷見雄二、村上雅英、安井昇 : 木造真壁の耐火性能予 測、日本建築学会構造系論文集、第 611 号、pp.165-170、2007.1

14）安井昇、長谷見雄二、平井宏幸、渡邊圭太、腰原幹雄、澤野恵直、小 川敦史、木村忠紀、山本幸一 : 横架材の加熱後曲げ応力度予測に基づ く伝統木造床の防耐火設計と梁長さ・間隔の拡張可能性、日本建築 学会構造系論文集 第 642 号、pp.1523-1529、2009.8

15) BERTIL FREDLUND $\ulcorner$ A MODEL FOR HEAT AND MASS TRANSFER IN TIMBER STRUCTURES DURING FIRE 」PhD Dissertation, LUNDUNIVERSITY, SWEDEN, 1988.5

16）(財)日本住宅・木材技術センター、構造用木材の強度試験マニュアル、 2010.3

17）飯島泰男: 木質構造の研究の現状と今後の課題 Part II, 日本木材学会 強度・木質構造研究会編、日本木材学会、pp.7-8、1994

18）鈴木達朗、加來千紘、長谷見雄二、上川大輔、安井昇、亀山直央、腰 原幹雄、長尾博文:木材の含水率が高温時の力学性能に及ぼす影響, そ の 1 針葉樹材 (スギ)の高温時ヤング係数・曲げ強度の把握、日本建築 学会大会学術講演梗概集、防火、pp.135-138、2015.9

19）加來千紘、鈴木達朗、長谷見雄二、上川大輔、安井昇、亀山直央、腰 原幹雄、長尾博文:木材の含水率が高温時の力学性能に及ぼす影響, そ の 2 広葉樹材 (ケヤキ)の高温時ヤング係数・曲げ強度の把握、日本建 築学会大会学術講演梗概集、防火、pp.121-122、2015.9 


\section{INFLUENCE OF WATER CONTENT ON THE MECHANICAL PROPERTIES \\ OF WOOD EXPOSED TO FIRE}

- Young's modulus and bending strength of Cryptomeria Japonica and Zelkova serrate under various water-containing states at elevated temperature -

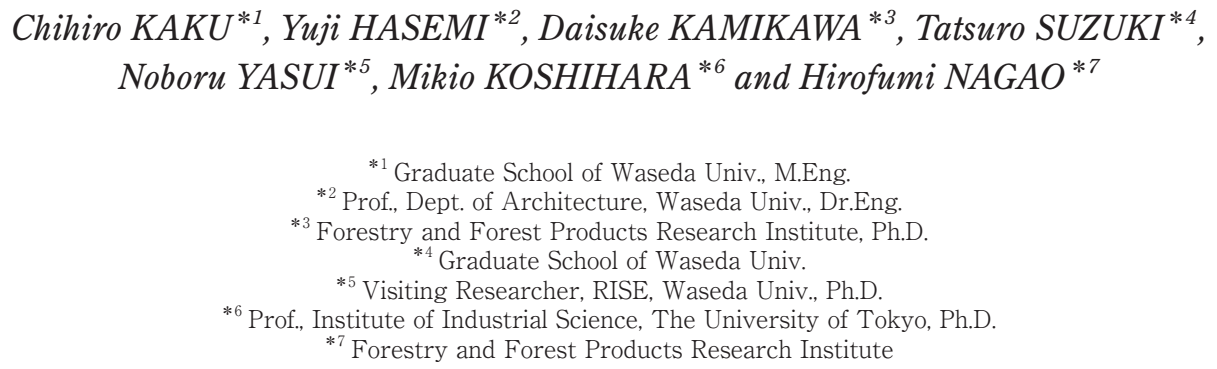

Public buildings in Japan are being increasingly constructed from wood. Timber-based buildings have been considered from various perspectives, including management of forest resources and environment concern. Large-scale buildings in Japan are needed to be fire-resistive or quasi-fire-proof constructions to withstand fire damage. If a fire breaks out a large-scale timber building, the residual strength of structural members exposed to fire must be known for the fire safety. For this purpose, study on physical properties of wooden structural members are important and influence of charring, temperature shift under heating and water content at normal temperature of wooden structural members have been studied. However influence of water content on the structural properties of wooden members under high temperature is not clearly.

In this paper, Cryptomeria Japonica, a softwood commonly used in timber engineering, and Zelkova serrata, a hardwood normally used in traditional large buildings, were heated up to $95^{\circ} \mathrm{C}$. The Young's modulus and bending strength of two species were measured at the elevated water content and temperatures. The results provide an engineering basis for the structural fire safety design of large-scale timber buildings. The following properties of the woods were analyzed and determined.

1. The effect of water content on Young's modulus and bending strength at elevated and normal temperatures.

2. The effect of heating on Young's modulus and bending strength at elevated water content.

3. Relationship between Young's modulus and bending strength in heated moisture state wood.

In the bending experiment, the mechanical properties of heated Cryptomeria Japonica and Zelkova serrate on a scale of 1 to 4 below water evaporation temperature (room temperature, $50^{\circ} \mathrm{C}, 80^{\circ} \mathrm{C}$ and $95^{\circ} \mathrm{C}$ ). The specimens were hewed from the two logs without knot and sized $20 \mathrm{~mm}$ square and $320 \mathrm{~mm}$ span (Fig.1). The water content of specimens was from 1 to $150 \%$ and divide into four groups. Group1 is low water content, under $5 \%$, Group2 is medium water content, between $5 \%$ and $15 \%$, Group3 is other medium water content, between $15 \%$ and $30 \%$, Group 4 is high water content, over $30 \%$. We used, as needed, a small dry kiln heated to $60{ }^{\circ} \mathrm{C}$ to drying. The bending test conformed to "The examination method for the bending strength" stipulated by JIS Z 2101 and was conducted in a compression testing machine with a heat-controlled chamber (Picture1). A flowchart of the experimental procedure is presented in Fig.2.

The Young's modulus of two species at elevated water content and temperatures, was largely affected by water content over $5 \%$ and heating temperatures $80^{\circ} \mathrm{C}$ or higher. The bending strength at normal temperature or higher was highly dependent on water content, however two species show different declining trends with the rise of water content and temperatures. The correlation between Young's modulus and bending strength of Cryptomeria Japonica and Zelkova serrate keep to the same with the rise of water content and temperatures. This study reports an experimental assessment of structural fire safety on large-scale timber building. 